\title{
The genus Sellaphora: an addition and corrections
}

\author{
David G. MANN \\ Royal Botanic Garden Edinburgh, Inverleith Row, Edinburgh EH3 5LR, Scotland, UK \\ e-mail:d.mann@rbge.org.uk
}

\begin{abstract}
Examination of further British specimens of Sellaphora species from Blackford Pond, Edinburgh, revealed that the 'spindle' deme described in a previous paper [D.G. MANN et al. (2008). Fottea 8: 15-78] was incorrectly characterized. Two demes were conflated: true 'spindle' and a further deme referred to here as 'cf. auldreekie'. The cox1 DNA Barcode specified for 'spindle' by MANN et al. (2008) was correct, but was linked to the wrong illustrations and description, which were of 'cf. auldreekie'. These errors and three references to a slide preparation are corrected.
\end{abstract}

Key words: Bacillariophyta, diatoms, DNA BARCODE, iconograph, Sellaphora, taxonomy

MANN et al. (2008) provided descriptions and illustrations of the larger-celled species of Sellaphora occurring in the British Isles. Our study was based on visual comparisons of many light micrographs and applied the well-known 'rules' of allometric change during the life cycle, established by GeiTLER (1932) and others, to group specimens into demes (putative species, deserving further study before being given formal recognition). Many of these demes were only very subtly different. Some may prove to be inseparable morphologically, though genetically distinct. Others may prove to be conspecific. In either case, significant progress in understanding is likely to be achieved through use of molecular data. Therefore, we specified DNA 'barcodes' wherever possible, to facilitate consistent identification. This procedure is the molecular equivalent of specifying a type specimen and it shares the same weakness: type specimens determine which name should be applied to each group of organisms considered to be a distinct species, but they do not and cannot determine whether the groups are distinct nor the range of variation to be found within them. In our Sellaphora study, the barcodes were necessarily derived from clonal cultures, whereas the species and deme descriptions were based on interpretation of variation in natural populations, as they have to be if a taxonomy is to be usable by ecologists and palaeoecologists. Unfortunately, I made a mistake in one case and linked a barcode to the wrong description. The error affects the deme illustrated and described as 'spindle' by MANN et al. 2008 (p. 49) and arose because of a change in the Sellaphora flora of the 'type locality', Blackford Pond.

The barcoded clone of 'spindle' (BLA16 = KE 68) was small-celled when vouchered and was illustrated by Evans et al. (2008, fig. 9i). This clone was used by Evans et al. (2008) to obtain $r b c \mathrm{~L}$ and $18 \mathrm{~S}$ rDNA data, and by EvANS et al. (2007) to obtain the cox 1 sequence subsequently specified as the DNA barcode of 'spindle' by MANN et al. (2008). The 'spindle' deme is currently abundant in Blackford Pond but it was absent or uncommon in the samples of natural epipelon studied in detail for MANN et al. (2008), most of which were collected between 1983 and 2004. Because I initially found no better morphological matches for clone BLA16 among these natural Blackford samples, I wrongly conflated two demes, assuming that the BLA16 'spindle' clone must belong to the deme MANN et al. (2008) illustrated as fig. 33. This deme was therefore referred to as 'spindle' and typified by DNA barcode sequence GenBank EF164951, obtained from BLA16. Examination of newer samples of natural epipelon from Blackford Pond and clones isolated since 2005 show that BLA16 in fact exemplifies a different deme, which is by definition and precedent (Evans et al. 2007, 2008) the true 'spindle'. Here, I provide a description of the true 'spindle', based on recent collections from Blackford Pond from which confirmatory coxl-backed identifications have 
been made (for 10 further clones, all collected in November 2005). The deme wrongly referred to as 'spindle' by MANN et al. (2008) is renamed here as 'cf. auldreekie'; for this deme I repeat the incorrectly attributed illustrations and description provided earlier, in order to prevent readers having to make constant cross-reference to the original paper. No cox 1 barcode is yet available for $\Phi$ 'cf. auldreekie'.

A final error to be corrected concerns the legends to figs 33, 34 and 36 in MANN et al. (2008), which refer to $S$. [pupula] $\Phi$ 'cf. auldreekie' (fig. 33: see below), $S$. auldreekie (fig. 34) and $S$. [pupula] $\Phi$ 'urban elliptical' (fig. 36). All of the photographs in these figures show specimens from a single slide of Blackford Pond material collected in 2004. The slide was renumbered during our study and so, in each of the legends, 'E2004/2' should be replaced by 'E3667/2', in agreement with table 3 of MANN et al. (2008).

All naming conventions, sources, material and methods are as specified by MANN et al. (2008).

\section{Sellaphora [pupula K-LB] Ф 'spindle' (Fig. 1)}

Valves linear-elliptical, with broad, slightly

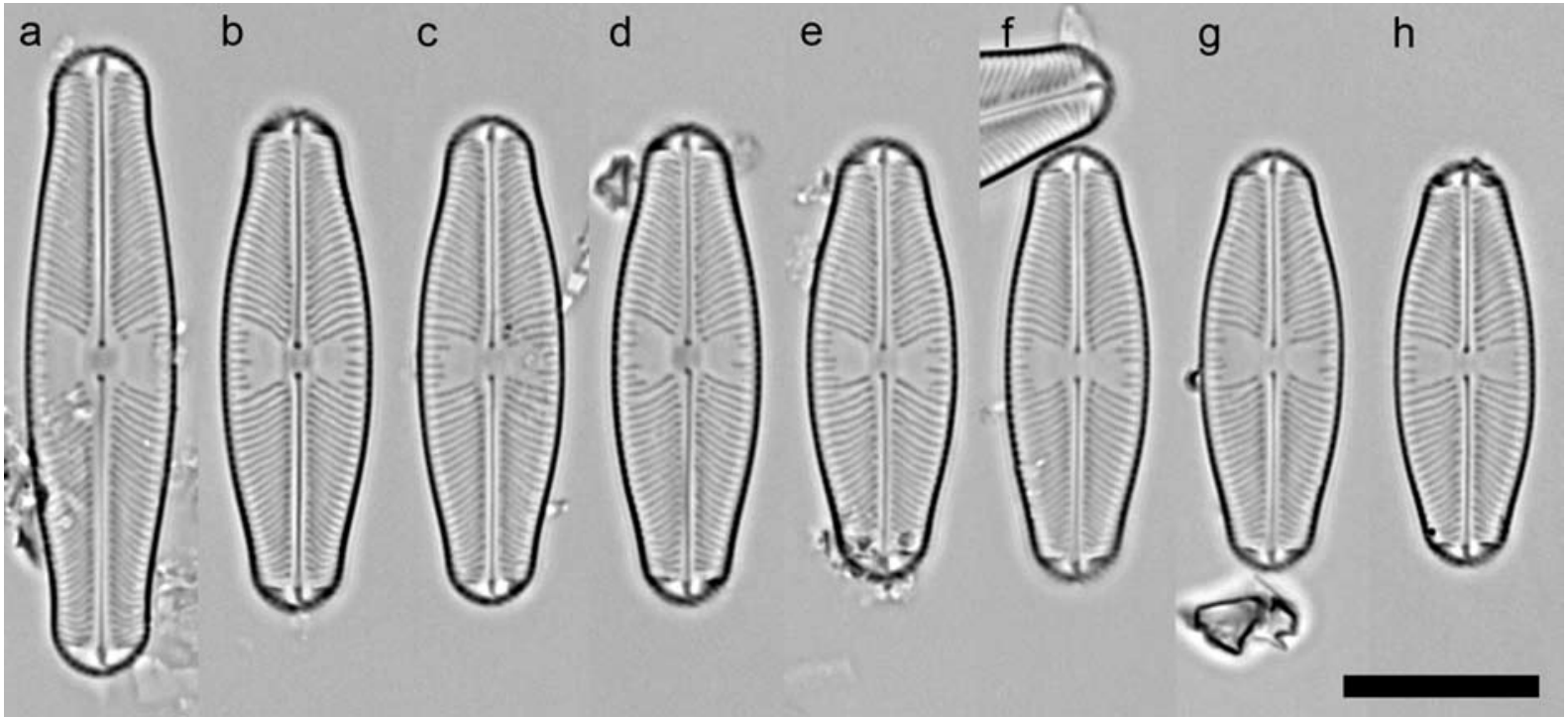

Fig. 1. Sellaphora [pupula K-LB] $\Phi$ ‘spindle’: Blackford Pond, slide E3578/3 (collected November 2005). Scale bar $10 \mu \mathrm{m}$.

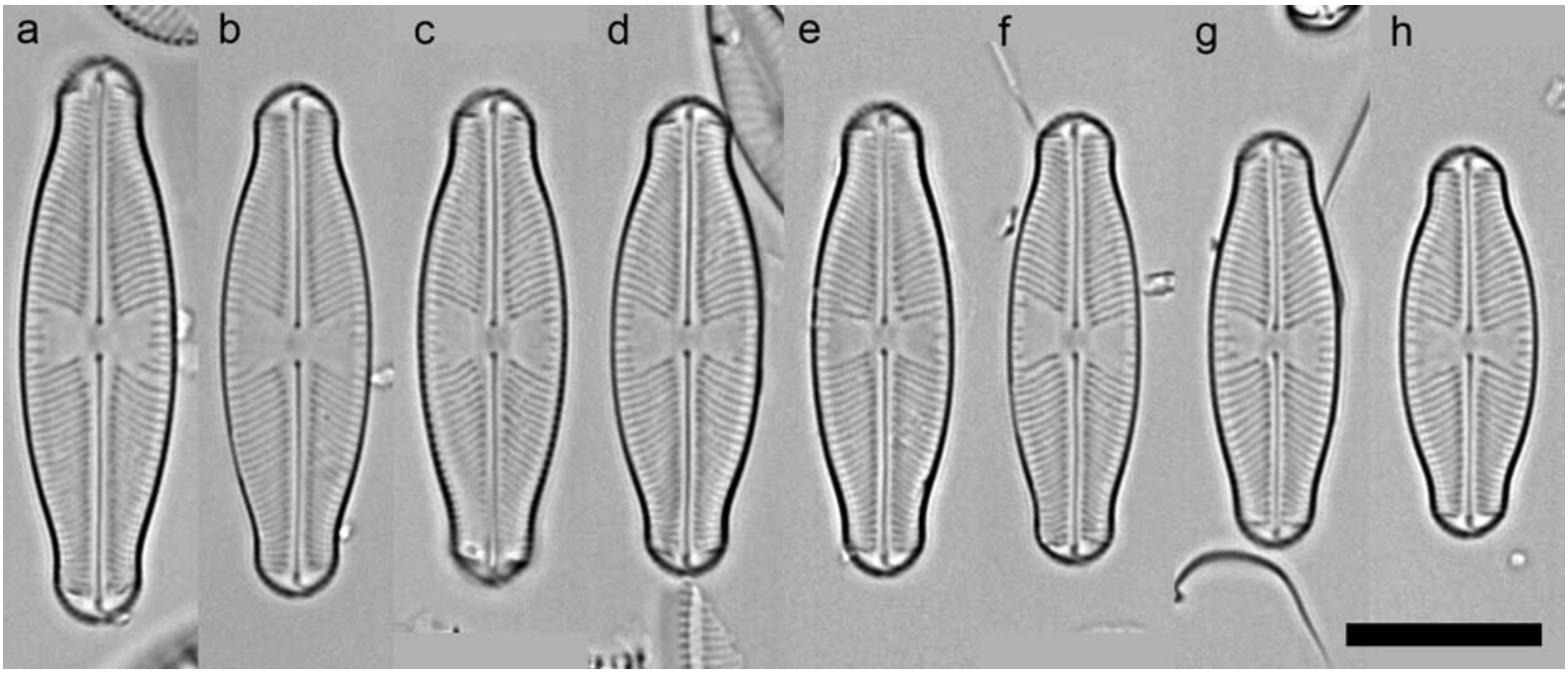

Fig. 2. Sellaphora [pupula K-LB] $\Phi$ 'cf. auldreekie': Blackford Pond (as $\Phi$ 'spindle' in MANN et al. 2008, fig. 33). (a-h) slide E3667/2 (collected November 2004). In (c), some striae appear punctate because of missing areolae. Scale bar $10 \mu \mathrm{m}$. 
rostrate poles, $20.5-32.0 \times 7.0-7.75 \mu \mathrm{m}$. Striae slightly curved, radiate, becoming parallel (even slightly convergent in the longest specimens) and sometimes angled near the poles, with some intercalated shorter striae at the centre, 20.7-21.722.3 in $10 \mu \mathrm{m}$; areolae invisible in LM. Axial area very narrow. Central area expanded (to $60-75 \%$ of the valve width), somewhat irregular, \pm bowtie-shaped. No obvious groove alongside the raphe-sternum. Raphe very slightly sinuous. Polar bars present, parallel or slightly convergent (in long specimens). DNA BARCODE (COX1): GenBank EF164951.

Remarks: $\Phi$ 'spindle' is similar to $\Phi$ 'little' (ManN et al. 2008, fig. 32) but the poles of the valves are noticeably broader and the valve centres are slightly wider; $\Phi$ 'little' has slightly coarser striation (c. 19-21 in $10 \mu \mathrm{m})$.

Sellaphora [pupula K-LB] $\Phi$ 'cf. auldreekie' (Fig. 2, previously published by MANN et al. 2008, fig. 33)

Valves narrowly elliptical with rostrate (sometimes slightly capitate) poles, $20-29 \times 6.25-8 \mu \mathrm{m}$. Striae straight or slightly curved, radiate, becoming parallel and sometimes angled near the poles, with some intercalated short striae at the centre, 18.920.7-21.7 in $10 \mu \mathrm{m}$; areolae invisible in LM (here and elsewhere in Sellaphora, striae can sometimes appear dotted when some areolae are missing). Axial area very narrow. Central area very strongly expanded (to $70-80 \%$ of the valve width), \pm welldefined, bow-tie-shaped. No obvious groove alongside the raphe-sternum. Raphe very slightly sinuous. Polar bars present, parallel or slightly convergent (in long specimens).

REMARKS: $\Phi$ 'cf. auldreekie' is similar to $S$. paenepupula (Metzeltin \& Lange-Bertalot 2002, p. 66, pl. 31, figs 9-15) in shape and stria pattern but is slightly larger and more coarsely striated (c. 21, rather than 23-24 in $10 \mu \mathrm{m})$. Sellaphora paenepupula was described from the River Ivato, Madagascar, and Metzeltin \& LangeBERTALOT stated that they had not observed the species in other parts of the world. $\Phi$ 'cf. auldreekie' is also similar to S. auldreekie (MANN et al. 2004; MANn et al. 2008, fig. 34), from which it differs in its wider poles, and to $\Phi$ 'little' (MANN et al. 2008, fig. 32), from which it differs in its slightly more strongly rostrate poles and a more swollen outline at the centre.

\section{References}

Evans, K. M., Wortley, A. H. \& Mann, D. G. (2007): An assessment of potential diatom "barcode" genes (cox 1 , $r b c \mathrm{~L}, 18 \mathrm{~S}$ and ITS rDNA) and their effectiveness in determining relationships in Sellaphora (Bacillariophyta). - Protist 158: 349-364.

Evans, K. M., Wortley, A. H., Simpson, G. E., Chepurnov, V. A. \& ManN, D. G. (2008): A molecular systematic approach to explore diversity within the Sellaphora pupula species complex (Bacillariophyta). - J. Phycol. 44: 215-231.

Geitler, L. (1932): Der Formwechsel der pennaten Diatomeen (Kieselalgen). - Arch. Protistenk. 78: 1-226.

Mann, D. G., McDonald, S. M., Bayer, M. M., Droop, S. J. M., Chepurnov, V. A., Loke, R. E., Ciobanu, A. \& Du Buf, J. M. H. (2004): Morphometric analysis, ultrastructure and mating data provide evidence for five new species of Sellaphora (Bacillariophyceae). - Phycologia 43: 459-482.

Mann, D. G., Thomas, S. J. \& Evans, K. M. (2008): Revision of the diatom genus Sellaphora: a first account of the larger species in the British Isles. - Fottea 8: 15-78.

Metzeltin, D. \& Lange-Bertalot, H. (2002): Diatoms from the "Island Continent" Madagascar. - In: LANGeBertalot, H. (ed.): Iconographia diatomologica. Annotated diatom micrographs. Vol. 11. TaxonomyBiogeography-Diversity. - 286 pp., A.R.G. Gantner, Ruggell, Liechtenstein.

(C) Czech Phycological Society

Received May 1, 2008

Accepted July 15, 2008 